Zbigniew Jan STAŃCZYK

\title{
Dwa rodzaje kapitału społecznego
}

\section{Ogólna charakterystyka kapitału społecznego}

Termin kapitat spoteczny zostal wprowadzony do nauk spolecznych przez Glenna Loury'ego w jego badaniach dyskryminacji rasowej w Stanach Zjednoczonych ${ }^{1}$. Jednak już wcześniej pojawialy się pojedyncze użycia tego terminu. Prawdopodobnie pierwszy raz zastosowata go w 1920 r. Lyda Hanifan określajac nim "te rzeczywiste aktywa, które najbardziej liczq się w codziennym życiu ludzi, a mianowicie: dobra wola, towarzyskość, wspótczucie i kontakty spoleczne pomiędzy jednostkami i rodzinami, które tworza byty spoleczne"2. Sam Loury użyt go natomiast w celu opisania tych zasobów, które stanowiq „więzi rodzinne i spoleczne organizacje wspólnot lokalnych użyteczne w umystowym i spotecznym rozwoju dzieci i mtodych ludzi. Zasoby te sq różne dla różnych osób i mogq stwarzać istotne przewagi w rozwoju kapitalu ludzkiego u dzieci i mlodziezy" 3 .

Pomysł Loury'ego został podchwycony przez socjologa Jamesa Colemana, który w swoich pracach wiele miejsca poświęcił analizie pojęcia kapitału społecznego. Analizy te zajmują poczesne miejsce w jego fundamentalnej pracy pt. Podstawy teorii spolecznej ${ }^{4}$. Dzięki Colemanowi kapitał społeczny stał się popularnym tematem w naukach społecznych. Praca Colemana nie ograniczała się do analiz teoretycznych. Przeprowadzał on również badania empiryczne nad wpływem kapitału społecznego, w postaci wspólnot związanych z katolickimi prywatnymi szkołami w Ameryce, na poziom nauczania w tych szkołach.

\footnotetext{
Autor jest pracownikiem naukowym Akademii Ekonomicznej w Krakowie.

1 G. Loury, A dynamic theory of racial income differences, w: P.A. Wallace i A. Le Mund (red.). Women, Minorities, and Employment Discrimination", Lexington Books, Lexington, Mass, 1977. Uwagi Loury ego o kapitale spolecznym zawarte są również w jego artykule z 1987 roku pt. Why should we care about group equality? opublikowanym w .Social Philosophy and Policy", t. 5, s. 249-271.

2 L.J. Hanifan, The Community Center. Silver, Burdette, and Co., Boston, 1920. Cyt za M. Woolcock Social capital and economic development: Toward a theoretical synthesis and policy framework, „Theory and Society", 1998, t. 27, s. 192. Jeśli chodzi o inspiracje w tworzeniu pojẹcia kapitalu spolecznego, to zdaniem niektórych autorów należałoby się cofnąć co najmniej do Hume'a, Smitha i Burke'a.

3 J.S. Coleman Foundations of Social Theory, Belknap Press of Harvard University Press. Cam. bridge, Mass, 1990, s. 300.

4 J.S. Coleman, Foundations of Social Theory, op. cit.
} 
Badaniem wpływu kapitału społecznego na efektywność instytucji politycznych zająl się w szczególności Robert Putnam w swej klasycznej juź pracy o demokracji we Włoszech ${ }^{5}$. Kolejnym autorem, który przyczynił się do wielkiej popularności pojęcia kapitału spolecznego jest Francis Fukuyama ${ }^{6}$. Początkowo spotkało się ono z wielkim zainteresowaniem przede wszystkim socjologów i politologów, ale od kilku lat staje się również intensywnym przedmiotem badań ekonomistów. Artykuły o zaufaniu i kapitale społecznym ukazały się w takich renomowanych periodykach głównego nurtu ekonomii jak American Economic Review, Journal of Political Economy i Quarterly Journal of Economics. Powoli wkracza ono również do polskojęzycznej literatury z zakresu nauk społecznych ${ }^{7}$. Wynikami badań dotyczących kapitału społecznego zainteresowane są nie tylko środowiska akademickie, ale ostatnio równiez̉ Bank Światowy. Termin kapitał społeczny pojawia się także w debatach politycznych ${ }^{8}$.

Rosnąca rola pojęcia kapitału społecznego jest, z jednej strony, świadectwem unifikacyjnych tendencji w naukach społecznych polegających na przenoszeniu pojęć i metod ekonomii do innych dyscyplin. Tendencje takie bywają nazywane „imperializmem ekonomii"9. Z drugiej strony, na dyskusje o kapitale społecznym, w szczególności w początkowej fazie, wpłynęła również tzw. nowa socjologia gospodarcza, która wskazywała na niedostatki podejścia ekonomicznego ${ }^{10}$. Jak to później będę starał się wykazać, wpływ ten nie był jednoznacznie pozytywny, gdyż zgodne z sugestiami nowej socjologii gospodarczej, utożsamianie kapitału społecznego z dość trwałymi sieciami powiązań między ludźmi, niepotrzebnie zawęzilo zakres zastosowania tego pojęcia i odwróciło uwagę od wielu mechanizmów związanych z kształtowaniem się współpracy w różnych spoleczeństwach.

Najbardziej ogólne określenia kapitału społecznego zostały sformułowane po raz pierwszy w pracach Jamesa Colemana: „jest on [kapitał społeczny] zdefiniowany przez swoją funkcję. Nie jest to pojedynczy byt, ale szereg różnych bytów, które mają dwie wspólne cechy: składają się z jakiś aspektów struktury społecznej i ułatwiają pewne działania jednostek, które są wewnątrz tych

5 R.D. Putnam Demokracja w dzialaniu: Tradycje obywatelskie we wspólczesnych Wloszech, Znak, Kraków, 1995.

- Por. F. Fukuyama Zaufanie: Kapital spoleczny a droga do dobrobytu, PWN, Warszawa, 1997.

7 A. Matysiak Źródla kapitalu spolecznego, Wydawnictwo Akademii Ekonomicznej im. Oskara Langego, Wrocław, 1999.

8 Na przykład w niedawno opublikowanym manifeście polityçnym przywódcy Wielkiej Brytanii i Niemiec, Tony Blair i Gerhard Schröder stwierdzają, że najważniejszym zadaniem państwa jest inwestowanie w kapital ludzki i w kapitał spoleczny. Innym przykładem może byc wplyw Roberta Putnama na kształtowanie się ideologii środowisk Partii Demokratycznej skupionych wokół Billa Clintona.

9 Por. G. Radnitzky i P. Bernholz (red.) Economic Imperialism: Economic Approach Applied Outside the Field of Economics, Paragon House, Nowy Jork, 1987. Obecna kariera pojęcia kapitał społeczny może po części wynikać z nadziei na jego wielką stymulującą rolę, równą tej, jaką pelniło stworzone w latach 60. przez Schultza i Beckera pojẹcie kapitału ludzkiego.

10 Początkowo dominacja .kolektywistycznych" interpretacji pojęcia kapitału spolecznego mogła wynikać również z rosnącej w latach 80. popularności komunitaryzmu. 
struktur. Podobnie do innych form kapitału, kapitał społeczny charakteryzuje się produktywnością, umożliwiając osiągnięcie pewnych celów, które byłyby nieosiągalne pod jego nieobecność"11. Tego rodzaju określenie wydaje się być nie kontrowersyjne i bywa ono przyjmowane jako punkt wyjścia przez wielu autorów. Kłopoty pojawiają się jednak, gdy zaczyna się, co wydaje się być konieczne dla pokazania zaleźności przyczynowych, opisywać struktury lub relacje składające się na kapitał społeczny. Czasami takie opisy uwikłane są w funkcjonalne określenie tego pojęcia. Na przykład w innej pracy Coleman pisał, że „kapitałem społecznym jest każdy aspekt nieformalnej organizacji społecznej, który konstytuuje zasoby produkcyjne dla jednego lub wiẹkzej ilości podmiotów"12. Tak więc oprócz wskazania funkcji jaką pełni kapitał społeczny, Coleman wskazuje, że to nieformalne - w odróźnieniu od formalnych - organizacje, tworzą kapitał spoleczny.

Taką samą strategię można odnaleźć równieź u Roberta Putnama, który powołuje się na ogólne (funkcjonalne) określenia Colemana i dodaje następnie, że „kapitał społeczny odnosi się (...) do takich cech społeczeństwa, jak zaufanie, normy i powiązania, które mogą zwiększyć sprawność społeczeństwa, ułatwiając skoordynowane działania"13. Fukuyama też powołuje się na Colemana i wyjaśnia, że omawiany tu termin oznacza „umiejętności współpracy międzyludzkiej w obrębie grup i organizacji w celu realizacji wspólnych interesów"14.

Podobne określenia można znaleźć u wielu innych autorów. Alejandro Portes pisze, że pojęcie kapitału społecznego „odnosi się do możliwości jednostek do panowania nad rzadkimi zasobami na mocy członkostwa w sieci powiązań lub w szerszej strukturze spolecznej"15.

Natomiast Ronald Burt stwierdza, że kapitał spoleczny to „przyjaciele, współpracownicy, i ci wszyscy, których znamy i dzięki którym uzyskujemy możliwoŚci użycia [innych form] kapitału... Związki wewnątrz firm i pomiędzy firmami są kapitałem społecznym"16. Bardziej skomplikowane określenie oferuje

11 J.S. Coleman, Foundations of Social Theory, op. cit., s. 302.

12 J.S. Coleman, A rational chotce perspective on economic sociology, w: N.J. Smelser i R. Swedberg (red.). „The Handbook of Economic Sociology”, Princeton University Press, Princeton. 1994, 5. 170. W tym samym akapicie podaje on przyklady kapitalu spolecznego: _Silne normy społeczne we wspólnocie, które odciagają młodzież od kultury masowej i zarazem nakierowują ją na szkołę, konstytuują kapital spoleczny dla rodzicôw, którzy zainteresowani są szkolnymi sukcesami swoich dzieci. Dla studentów studiów doktoranckich, zwarta grupa pracująca nad tymi samymi problemami konstytuuje kapital spoleczny dla studiowania dla kaz. dego członka tej grupy, Rozległa sieć przyjaciół i znajomych, poprzez którą można dowie. dzieć się o nowych możliwościach pracy, stanowi kapitał społeczny dla poszukującego jej."

13 R. Putnam, op. cit., s. 258.

14 F. Fukuyama, op. cit., S. 20.

15 A. Portes, Economic sociology and the sociology of immigration; a conceptual overview. W: A. Portes (red.). .The Economic Sociology of Immigration: Essays on Networks, Ethnicity and Entrepreneurship", Russell Sage Foundation, Nowy Jork, 1995, s. 12. Cyt. za: M. Woolcock, op, cit., S, 189-190.

16 R. Burt Structural Holes, Harvard University Press, Cambridge, Mass., 1992. 
socjolog francuski Pierre Bourdieu. Według niego kapitał społeczny ,jest sumą zasobów, rzeczywistych lub wirtualnych, które przypadają jednostce lub grupie z mocy posiadania trwałej sieci mniej lub bardziej zinstytucjonalizowanych relacji wzajemnej znajomości i uznania"17.

Użycie słowa kapitał powinno mieć oczywiście uzasadnienie: aby nie powodować terminologicznego zamieszania nie powinno ono odbiegać od jego tradycyjnego stosowania. Oczywiście, jak to zazwyczaj bywa z terminami w naukach społecznych, nie ma jednej powszechnie przyjętej jego definicji. Zdarza się nawet, że słowniki ekonomiczne podają kilka alternatywnych definicji. Przeważająca większość określeń zawiera jednak wspólne elementy. Po pierwsze, kapitał jest jakimś zasobem, i po drugie, dzięki niemu można wygenerować lub przyczynić się do wygenerowania strumienia jakichś korzyści, np. dochodów lub usług. Bywa też, że w celu odróżnienia od zasobów naturalnych podkreśla się, że kapitał jest czymś stworzonym przez człowieka. Na przykład Graham Bannock, Ron Baxter i Evan Davis w podręcznym słowniku ekonomii podają dwa znaczenia słowa „kapitał”. Mogą nim być: „aktywa, które są zdolne do wygenerowania dochodu i które same zostały wyprodukowane” lub „w bardziej ogólnym sensie, każde aktywa lub każdy zasób aktywów - finansowych lub rzeczowych - zdolnych do wygenerowania dochodu". Ten sam słownik objaśnia również znaczenie terminu „kapitał ludzki” - są to „umiejętności i wiedza ucieleśnione w sile roboczej” - oraz dodaje, że „inwestycje w kapitał ludzki zwiększają produktywność pracy w ten sam sposób jak inwestycje w maszyny"18.

Zaproponowane przez Colemana określenie kapitału społecznego wydaje się być bliskie standardowemu sposobowi używania słowa kapitał w ekonomii ${ }^{19}$. Co więcej, w jego pracach zawarte są sformułowania, które wprost podkreślają, że kapitał społeczny pełni tę samą funkcję, co inne formy kapitału. Między innymi pisał on, że „Kapitał rzeczowy i ludzki ułatwiają działalność produkcyjną - kapitał społeczny czyni to samo"20. Pomimo tych podobieństw zachodzą duże różnice między kapitałem społecznym (nawet w ujęciu zaproponowanym przez Colemana i w analogicznych ujęciach) i innymi formami kapitału, oto one:

17 P. Bourdieu i L. Wacquant, Invitation to Reflexive Sociology, University of Chicago Press, Chicago, 1992. Cyt. za: M. Woolcock, op. cit, s. 189. Bourdieu ma szczególne upodobanie do wynajdywania nowych rodzajów kapitału - w jego pismach moźna znaleźć omówienie co najmniej sześciu rodzajów kapitalu związanych z życiem spolecznym.

18 G. Bannock, R.E. Baxter i E. Davis, Dictionary of Economics, Penguin Books, Londyn, 1987. S. 58 .

19 Istnieją też określenia kapitału społecznego, które daleko odbiegają od propozycji Colemana. Na przyklad, polski socjolog. Wnuk-Lipiński (E. Wnuk-Lipiński, Demokratyczna rekonstrukcja, Wydawnictwo Naukowe PWN, Warszawa, 1996, s. 151) pisze, że kapitał społeczny to „ogót nieformalnych powiązań społecznych (czyli znajomości), dzięki którym jednostka podwyższa swoje prawdopodobieństwo wejścia do elity lub utrzymania pozycji w elicie". Propozycja Wnuka-Lipińskiego nie będzie tu analizowana wlaśnie dlatego, że jest zbyı daleko innowacją w stosunku do tego, co zazwyczaj jest kojarzone z koncepcją kapitału spolecznego.

20 J.S. Coleman, Foundations of Social Theory, op. cit., s. 304. 
- Kapitał rzeczowy i ludzki są w zasadzie cechami pojedynczych bytów. Pojęcie kapitału społecznego opisuje relacje między ludźmi (lub nawet grupy ludzi).

- „Inwestowanie” w kapital spoleczny jest zapewne trudniejsze niż w inne rodzaje kapitału, jeśli powstaje on jako skutek uboczny działań nakierowanych na inne cele (a nie na zwiększanie kapitału społecznego).

- Kapitał rzeczowy może być częściowym substytutem dla pracy. Trudno sobie coś takiego wyobrazić w przypadku kapitału społecznego. Inwestowania w kapital ludzki i społeczny może mieć charakter komplementarny (np. rodzice mogą zarazem wpływać na rozwój intelektualny dziecka i na jakość relacji między nimi a dzieckiem).

- Zasób kapitału rzeczowego ulega zmniejszeniu na skutek zużycia. Z kapitałem społecznym bywa czasami na odwrót.

- Kapitał rzeczowy i ludzki tworzone sạ przez świadome decyzje ludzi. Kapitał społeczny moźe pojawiać się również (według niektórych - jedynie) jako niezamierzony efekt świadomych działań.

- Kapitał społeczny, o ile w ogóle może się przemieszczać, jest mniej mobil. ny od kapitału rzeczowego.

- W o wiele większym stopniu kapitałowi społecznemu, w porównaniu z rzeczowym i ludzkim, przysługuje następująca cecha: jest on trudno i powoli stwarzany, a bardzo szybko (czasami nawet natychmiast) może ulec zniszczeniu.

- Kapitał ludzki i społeczny mogą być uznawane również jako wartości same w sobie. Kapitał rzeczowy ma jedynie, przynajmniej we współczesnych społeczeństwach, wartość instrumentalną.

- Zasób kapitału ludzkiego trudniej zmierzyć niż zasób kapitału rzeczowego. Jeszcze trudniejsze jest mierzenie zasobu kapitału społecznego ${ }^{21}$.

Coleman w swych Podstawach teorii spolecznej zamieścił prosty rysunek ilustrujący pierwszą z wymienionych różnic pomiędzy kapitałem ludzkim i kapitałem społecznym²2. Rysunek przedstawia trzyosobową strukturę społeczną. Kapitał ludzki jest ucieleśniony w osobach tworzących tẹ strukturę (wierzcholki trójkąta), a kapitał społeczny - w relacjach pomiędzy tymi osobami (kreski łączące wierzchołki).

21 Por. M. Woolcock, op. cit., s. 191. F. Fukuyama, op. cit., s. 39, pisze, że kapitał spoleczny jest formą kapitału ludzkiego. Według niego jedną z cech wyróżniających kapitał spoleczny jest to, że tworzony i przekazywany jest on za pośrednictwem mechanizmów kulturowych: religii, tradycji, historycznego nawyku.

22 J.S. Coleman, Foundations of Social Theory, op. cit, s. 305 
Rys. 1. Ilustracja różnicy pomiẹdzy kapitalem ludzkim i spolecznym

A.

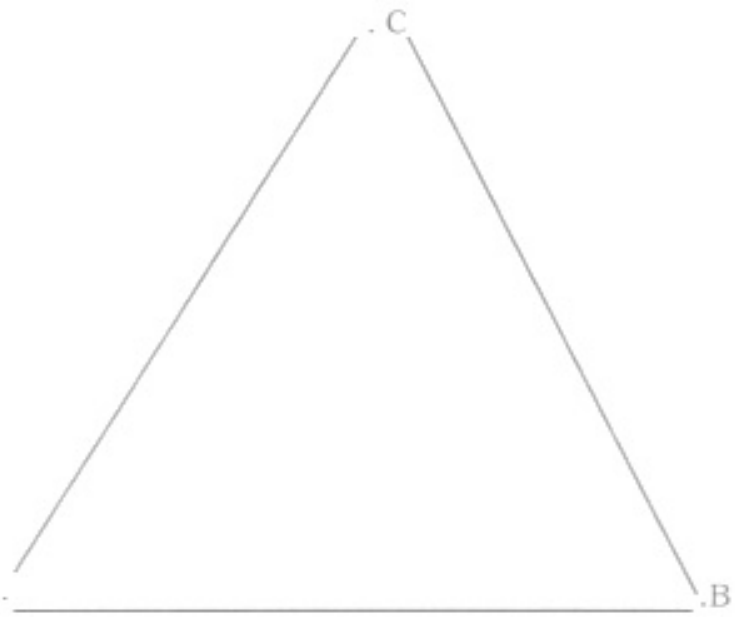

Jeżeli kapitał społeczny określony jest poprzez funkcje jakie spełnia, to należy następnie rozstrzygnąć jakiego rodzaju relacje tworzą kapitał. Coleman pisze o relacjach zaufania i wladania (ang. authority) ${ }^{23}$. Interpretując stwierdzenia zawarte w najwaźniejszej pracy Putnama, Demokracji w działaniu moźna by powiedzieć, że są to relacje zaufania i wzajemności. Taka charakterystyka, jak to będzie później pokazane, może jednak nie być wystarczająca. Aby uzupełnić tę charakterystykę autorzy piszący o kapitale społecznym dodawali, explicite lub implicite, dodatkowe cechy do opisu relacji tworzących kapitał spoleczny (uczynił to także Putnam). Na przykład twierdzono, że jeśli ma pojawić się znaczący efekt, to ilość relacji nie moźe być mała i muszą one być ze sobą powiązane. W celu podkreślenia tego faktu, w latach 80 . spopularyzowano termin „sieć powiązań”, o którym jeszcze bẹdzie mowa w następnych dwóch podrozdziałach.

Coleman wymienil trzy cechy powiązań (relacji) lub struktury społecznej, od których zależy „intensywność" kapitału społecznego. Są to: domknięcie sieci powiązań, ciąglość relacji spolecznych i wielorakość tychże relacji. Domkniẹcie powiązań to pozostawanie każdej, bẹdącej w danej strukturze, osoby w możliwe najwiẹkszej liczbie relacji w taki sposób, aby nikt nie stanowił „odgałęzienia" struktury. Dla struktury zlożonej z czterech osób domknięcie ilustruje prosty graf na rysunku 4.2 b.

23 Ibidem, 5, 300. 
Rys. 2. Ilustracja dwóch typów sieci powiązań: (a) niedomkniętej i (b) domkniętej

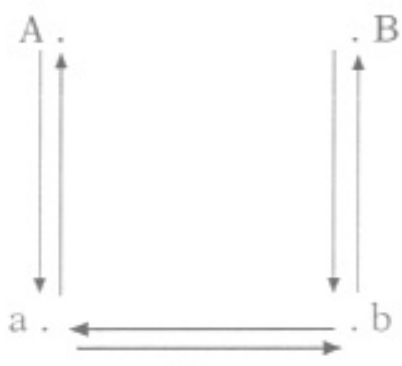

(a)

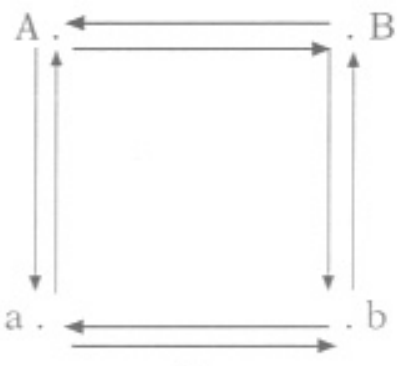

(b)

Żródło: J.S. Coleman, Foundation of Social Theory, s. 319, rys, 12.5.

Coleman bliżej nie wyjaśnił czym jest ciągłość relacji. Uznał on zapewne, że jest to pojęcie oczywiste. Wielorakość relacji polega natomiast na tym, że pomiędzy danymi osobami zachodzą relacje związane z więcej niż jedną działalnością lub z wiẹcej, niż jedną rolą.

\section{Kapitał społeczny jako sieć powiązań pomiędzy ludźmi}

Zasadniczy wpływ na określanie kapitału społecznego, jako sieci powiązań, miały prace socjologa Marka Granovettera i ekonomisty Yorama Ben-Poratha, choć żaden z nich nie używał tego terminu. Drugi z wymienionych autorów przeanalizował właściwości powiązań w sieciach. Powiązania te występują w rodzinie, pośród przyjaciół, a nawet pomiędzy firmami, i najważniejszą ich cechą jest tożsamość podmiotów nimi połączonych ${ }^{24}$. Dla Ben-Poratha paradygmatyczne są właśnie związki występujące w rodzinach, którym przysługują następujące cechy:

1. Związki te zachodzą w dłuższym okresie czasu, ale długość ich trwania nie jest wcześniej ustalona.

2. Obejmują one dużą ilość różnorodnych działań. Zasięg i ważność działań ulega zmianie.

3. Nie wszystkie szczególy umów, które są zazwyczaj bardzo nieformalne, są dokładnie określone. Wiele działań zależy od różnego rodzaju zdarzeń. Często reakcje na te zdarzenia zależą od ogólnych norm społecznych stosowanych w podobnych sytuacjach. Często też decyzje o reagowaniu na zdarzenia podejmowane są na bieżąco.

24 Ben-Porath pisze o „F-connection”, czyli o „polączeniu-F”. Litera F wzięła siẹ stąd, że, jak to zostało zaznaczone, „polączenie” to charakterystyczne jest dla rodzin, przyjaciól i firm, czyli dla „families", „friends" i „firms". 
4. Umowy składają się z wielu niezależnych składowych, których relatywne znaczenie trudno oszacować przy pomocy jakichś wag.

5. Nie ma wspólnej miary warunków szeroko rozumianej wymiany. Nie wystẹpuje też zbilansowanie indywidualnych wkładów we współpracę. Tolerowane jest nawet duży brak zbilansowania i zazwyczaj nie jest teź ściśle określone, kiedy i w jakich okolicznościach ten brak powinien być zrównany.

6. Chociaż przestrzeganie umów wynika przede wszystkim z motywacji wewnętrznych, to jednak występuje także pewien wspomagający nacisk społeczny.

7. Do pewnego stopnia umowy tworzą kolektywną tożsamość, która wpływa na transakcje z osobami będącymi poza "kolektywem”".

8. Najważniejszą cechą związków rodzinnych jest to, że są one „ucieleśnione w tożsamości czlonków rodziny". Związki i umowy tracą swe znaczenie bez tożsamości uczestniczących w nich osób. Mają one więc zawsze szczególny charakter, nie podlegają negocjacjom i nie mogą być transferowane'25.

Należy zaznaczyć, że w swych analizach Ben-Porath przyjmuje milcząco założenie o równości podmiotów pomiẹdzy, którymi zachodzą relacje. W swych analizach nie bierze on pod uwage możliwości podporządkowania jednego podmiotu przez inny podmiot.

Opisowi ostatniej z wymienionych cech, jak sam podkreśla najważniejszej, Ben-Porath poświęca dużo miejsca. Ma ona znaczne skutki ekonomiczne, gdyż może wpływać na specjalizację osób (i co za tym idzie, na efekty skali) oraz kształtować umowy i transakcje. Pomimo tego, rola tożsamości osób biorących udział w procesie gospodarowania, jest pomijana przez ekonomię. Przedstawiany przez podręcznikową ekonomię obraz gospodarki wygląda następująco: „Na rynkach działa wielu (...) kupujących i sprzedających. W idealną sytuację zakłada się doskonalą powtarzalność transakcji. Transakcje rynkowe zakładają istnienie ceny jednostkowej i wartość wyrażoną we wspólnej jednostce rozrachunkowej, która wskazuje możliwości zyskane i tracone przez strony biorące udział w transakcji. (...) Wartość realizowana poprzez wymianę nie zależy od tożsamości stron; wystarczająca informacja jest zawarta w cenowo-ilościowych ofertach i nic innego nie ma znaczenia dla stron dokonujących transakcji. (...) Jak to jest przedstawione przez podręczniki ekonomii na poziomie średnim, ekonomia zajmuje się podmiotami, które odarte są z tożsamości. Kupujący i sprzedający bez twarzy, gospodarstwa domowe i firmy, które na bazie funkcji celu (użyteczności lub zysku) z wysiłkiem wypracowują reguły decyzyjne, spotykający się natychmiast na rynku, aby wymienić po cenach równowagi standaryzowane dobra"26.

25 Y. Ben-Porath, The F-Comection: Families, Friends, and Fims and the Organization of Exchange, „Population and Development Review”, L. 6, 1980, s, 1-30.

20 Ibidem, s. 4. 
Ben-Porath nadmienia, że pewne próby uwzględniania toźsamości osób były podejmowane przy konstruowaniu modeli (np. przez Beckera) dla opisania związków, w których inna osoba była celem. Modele te jednak nie pasują to sytuacji, w których toźsamość ludzi wpływa na kształt transakcji, których celem może być zdobycie jakichś dóbr. Aby nie pozostawić wątpliwości w tej materii, Ben-Porath wyjaśnia, że „ekstremalne przypadki, w których tożsamość ma znaczenia, to związki uczuciowe: miłość i troska lub nienawiść skierowana na konkretną osobę, pragnienie przebywania w towarzystwie pewnych osób, lub unikania jakiejś grupy osób, itp. Takie związki w zasadzie znajdują się poza dziedziną zainteresowań ekonomii. Podejmowane przez ekonomistów próby zbadania niektórych konsekwencji takich związków polegały na wprowadzeniu funkcji użyteczności innych osób do funkcji uźyteczności danego indywiduum, co miało obrazować jego 'altruizm'27. Zdaniem Ben-Poratha, takie podejście nie rozwiązuje problemu przez niego postawionego - nie jest ono w stanie w sposób satysfakcjonujący opisać takich relacji, w których ludzie sa zainteresowani tożsamością innych ze względu na jakieś praktyczne cele, i zarazem takich, w których uczucia są tylko dodatkowym, występującym od czasu do czasu, czynnikiem.

W opinii Ben-Poratha istniały jednak przeslanki, aby twierdzić, że ekonomia zaczyna się zmieniać i staje się mniej odpersonalizowana. Jednym z przykładów podanych przez niego to teoriogrowe modele powtarzalnego dylematu więźnia, w którym nastẹpuje interakcja pomiędzy tymi samymi graczami. Inne świadectwa, które przywoluje na dowód tezy o zmianach w ekonomii sa jednak niezbyt liczne.

Sformułowana przez Ben-Poratha powyższa charakterystyka, mających wplyw na efektywne funkcjonowania spoleczeństwa i gospodarki powiązań miẹdzy ludźmi, jest zgodna z tym, co o sieci powiązań pisał Granovetter. Przyjął ją równieź Robert Putnam, który też uważa, że dobroczynne dla gospodarki i społeczeństwa sieci powiązań mają charakter osobowy, nieformalny, poziomy (horyzontalny) i są zaleźne od specyfiki grupy, której dotyczą. Pod pewnym względem jest bardzo bliski Granovetterowi, gdyż obaj uważają, że dla efektywności dzialań zbiorowych i dla sprawnego funkcjonowania wspólnoty „słabe więzi” (np. dobrowolna przynależność do jakiegoś stowarzyszenia) są ważniejsze od „mocnych więzi" (np. związki pokrewieństwa). Ponadto Putnam podkreśla, że te dobroczynne powiązania nie mogą być rezultatem jakiegoś projektu i że ich tworzenie się jest bardzo długotrwałym procesem.

Wraz ze wspólpracownikami Robert Putnam przeprowadzil, jak dotąd, najbardziej rozległe badania empiryczne nad rolą kapitału społecznego. W swych badaniach skupił się na funkcjonowaniu instytucji politycznych we Włoszech po reformie administracji w 1970 roku. Rezultatem pracy Putnama był wniosek, że to nie instytucje formalne (wprowadzone poprzez zmiany ustawodawstwa) ani nie specjalnie projektowana polityka decyduje o olbrzymich różni-

27 Ibidem, 5. 4. 
cach pomiędzy Północą i Południem Włoch. Decydującą przyczyną tego stanu rzeczy są tradycje zrzeszania się i aktywności w różnego rodzaju obywatelskich stowarzyszeniach i klubach. Innymi słowy przyczyna tkwi w ilości kapitału społecznego.

Putnam pisze, że na kapitał społeczny składają się również zaufanie i normy społeczne. Aby uniknąć analiz semantycznych i zarazem uczynić jego wypowiedzi spójnymi, można by przyjąć, że chodzi mu po prostu o takie powiązania między ludźmi, które oparte są na zaufaniu i na takich normach, jak norma wzajemności. Interpretacja ta może się oczywiście spotkać z zarzutem, że jest to nieuprawnione poprawianie autora. Być może istniały przyczyny dla których Putnam tak różne byty, jak powiązania między ludźmi, normy i zaufania, określił jednym terminem. Jest wielce prawdopodobne, że zawaźyły dwa następujące powody: po pierwsze intencja podkreślenia, że opis pojawiania się relacji zaufania, w którym użyte są narzędzia ekonomii (teoria gier, teoria kosztów transakcji i teoria działań kolektywnych) nie jest wystarczający, i po drugie, uczynienie opisu bardziej przystającym do funkcjonowania wielkich społeczeństw, gdzie powszechne normy wzajemności mają wpływ na kształtowanie się zaufania.

Putnam rozpoczyna analizy zjawiska współpracy od powołania się na teorię gier. Przytacza on ogólne warunki zachodzenia twierdzenia potocznego 28 oraz wnioski zeń wynikające, że przy nieskończenie wiele razy granym dylemacie więźnia możliwe są zarówno stany równowagi współpracy oraz braku współpracy. Dodaje on jednak, że zgodnie z twierdzeniem potocznym pozbawiona cech osobowych współpraca powinna być o wiele rzadsza niż jest to obserwowane w rzeczywistości. Następnie rozważa on rozwiązanie oferowane przez nową ekonomię instytucjonalną. Mianowicie, gdy wystẹpuje jakiś dylemat współdziałania (innymi słowy, gdy istnieją duże koszty transakcji uniemożliwiające współpracę), to współdziałanie mogą zapewnić formalne instytucje, np. moźliwość spisania kontraktu, który bẹdzie egzekwowany. Putnam uważa jednak, że nowa ekonomia instytucjonalna nie daje kompletnego wyjaśnienia, gdyż brak z kolei odpowiedzi na pytanie o to: jak moźliwe jest wykreowanie formalnych instytucji? Przecież one same są dobrem publicznym i tworzenie ich podlega logice działania zbiorowego: przy ich tworzeniu egoistycznie nastawione jednostki będą chciały pełnić rolę jeżdżących na gapę i, co za tym idzie, promujące współpracę instytucje formalne nie mają szans na zaistnienie. Zdaniem Putnama rozwiązaniem tego problemu jest istnienie wspólnoty i zaufania ${ }^{29}$.

28 W polskim wydaniu książki Putnama odpowiednikiem angielskiego wyrażenia ,folk theorem" jest „twierdzenie ludowe”. Obecnie częściej tlumaczone ono jest wlaśnie jako _twierdzenie potoczne".

29 R. Putnam, op. cit., s. 257. Putnam opiera tu swoje rozumowanie na artykule Roberta Batesa (R.H. Bates, Contra contractarianism: Some reflections on the new institutionalism, .Politics and Society", 1988, t. 16, s. 387-401). Dalej jednak nie zajmuje siẹ kwestią poczucia wspólnoty, ale tylko zaufaniem. 
W kolejnym akapicie zamieszcza on zdania, które wydają się być dokładniejszym wyjaśnieniem powyższej tezy. Pisze on, że „sukces w przezwyciężeniu dylematów zbiorowego działania (...) zależy od kontekstu, w którego ramach dana gra jest rozgrywana. Dobrowolna współpraca łatwiejsza jest w społeczności, która odziedziczyła istotny kapitał społeczny w postaci norm wzajemności i sieci obywatelskiego zaangażowania"30. W dalszej części swych rozważań stwierdza natomiast, że społeczne zaufanie rodzi się dzięki normom wzajemności oraz dzięki tzw. sieci obywatelskiego zaangażowania.

Nieżyczliwa próba odczytania argumentacji Putnama prowadziłaby z pewnością do sformułowania zarzutu występowania błędnego koła: warunkiem istnienia współpracy jest zaufanie, a z kolei zaufanie tworzy się na skutek współdziałania (np. w ramach sieci obywatelskiego zaangażowania). Jednakże interpretacja samego autora Demokracji $w$ dziataniu jest zgoła inna: to nie jest błędne koło, ale opis sprzężeń zwrotnych, które zapewniają równowagę ${ }^{3 !}$. Wyjaśnia on, że „Zaufanie społeczne, normy wzajemności, sieci obywatelskiego zaangażowania i skuteczna współpraca wzajemnie się wzmacniają. Do skutecznej wspólpracy instytucji potrzebne są zdolności nawiązywania kontaktów i zaufanie, ale te zdolności i to zaufanie są zaszczepiane i wzmacniane przez zorganizowaną współpracę. Normy i sieci obywatelskiego zaangażowania przyczyniają się do osiągnięcia dobrobytu i są z kolei wzmacniane przez ten dobrobyt". W przypisie dodaje on natomiast zdanie, które moźna uznać za najdobitniejsze sformułowanie argumentu dotyczącego związków przyczynowych zapewniających zaufanie w społeczeństwie: „wspólnota obywatelska jest samowzmacniającym się stanem równowagi" 32 .

Powyższe wyjaśnienie jest satysfakcjonujące przy wyjaśnianiu funkcjonalnych aspektów zaufania, działania sieci współpracy i instytucji je wspierających. Może ono być jednak niewystarczające dla wyjaśnienia genezy „samowzmacniających się wspólnot obywatelskich". Wydaje się, że należy przyjąć, że tym co pierwotne są osobiste i nieformalne sieci powiązań (które są na dodatek poziome). One wlaśnie wpływają na tworzenie się różnego rodzaju stowarzyszeń i one, w ostatecznej instancji, generują ogólnospołeczne normy i zaufanie. Powiązania te umożliwiają również bezpośrednio lub pośrednio, poprzez zaufanie i normy, współpracę nawet tam, gdzie bardzo mocno wchodzi w grẹ interes własny jednostek. Dzięki temu umożliwiają rozwiązywanie dylematów działania zbiorowego w nieformalny sposób oraz tworzenie formalnych instytucji rozwiązujących te dylematy. Pośrednie działanie sieci powiązań może się uwidaczniać w tym, że wykreowane w jednej sferze życia społecznego zaufanie może wpłynąć na koordynację działań w innej dziedzinie.

30 Ibidem, 5. 258.

31 Wiele z tych sprzęzeń zwrotnych jest przez Putnama przyjmowanych bez przedstawienia dopracowanych argumentów. Np. można by sobie wyobrazić, wbrew jego sugestiom, że w pewnych okolicznościach dobrobyt może ograniczyć zaangażowanie obywatelski, gdy ludzie wy. biorą pasywny, konsumpcyjny styl życia.

32 Ibidem, s. 282-283. 
Putnam w Demokracji $w$ dziataniu w niewielkim stopniu zwraca uwagę na kwestie gospodarcze, ale w artykule napisanym z Johnem Helliwellem stara się dowieść, że sieci obywatelskiego zaangażowania mają wplyw na rozwój gospodarczy ${ }^{33}$. Nawet jeśli uznać, że twierdzenie to jest dobrze potwierdzone dla Włoch, to wątpliwy jest jego uniwersalny charakter. Stephen Cohen i Gary Fields na przykładzie Doliny Krzemowej, pokazują, że nie ma związku pomiẹdzy siecią obywatelskiego zaangażowania i rozwojem gospodarki. Ich zdaniem w tym przypadku podstawą kreowania zaufania jest natomiast reputacja wynikająca z czyjegoś działania. Tego rodzaju zaufanie wplywało właśnie na szybki rozwój gospodarczy. Ponadto zaufanie oparte na reputacji może być lepsze od tego zaufania, które opisał Putnam, bo nie musi ono być ograniczone do swoich. Cohen i Fields uważają także, że dla Doliny Krzemowej ważniejsze od aktywności politycznej i społecznej mieszkańców były związki firm z Uniwersytetem Stanforda i z Uniwersytetem Kalifornijskim w Berkeley ${ }^{34}$.

Oprócz podkreślenia szczególnej roli sieci obywatelskiego zaangażowania bardzo istotne dla Putnama jest rozróżnienie poziomych (horyzontalnych) i pionowych (wertykalnych) powiązań. (W sieciach obywatelskiego zaangażowania występują poziome powiązania.). Wyjaśnia on, że „każde społeczeństwo - nowoczesne czy tradycyjne, autorytarne czy demokratyczne, feudalne czy kapitalistyczne - charakteryzuje się siecią przepływających między ludźmi informacji i wymian, tak formalnych, jak i nieformalnych. Niektóre z tych sieci są głównie 'poziome' i łączą osoby o porównywalnej pozycji i władzy. Inne są glównie 'pionowe', skupiające osoby nierówne sobie w asymetrycznych zależnościach hierarchii i podległości. W rzeczywistości naturalnie wszystkie sieci są mieszane, i pionowe, i poziome" 35 . Przykłady zasadniczo pionowych sieci to Kościół katolicki (sieci wiernych protestanckich są raczej poziome) i mafia (mafia jest chyba bardziej 'pionowa'). Poziome sieci, to różnego rodzaju dobrowolne stowarzyszenia (np. stowarzyszenia sportowe) oraz sieci obywatelskiego zaangażowania. „Sieci obywatelskiego zaangażowania są zasadniczą formą społecznego kapitału: im gęstsze w społeczeństwie są takie sieci, tym bardziej jest prawdopodobne, że obywatele będą w stanie wspólpracować dla wspól-

33 J.F. Helliwell i R.D. Putnam, Economic growth and social capital in Italy. Eastern Economic Journal", 1995, t. 21, nr 3. s. 295-307.

34 S.S. Cohen i G. Fields, Social capital and capital gains in Silicon Valley, _California Management Review", 1999, t. 41, nr 2, s. 108-130. Inna różnica miẹdzy poglądami Putnama na rozwój Włoch i Cohena oraz Fields na rozwój Doliny Krzemowej polega na tym, że według tego pierwszego na północy Wloch silne byly kilkusetletnie tradycje obywatelskie. Cohen i Fields podkreslają natomiast, że tradycje Doliny Krzemowej są bardzo krótkie - pierwszą firmę, był to Hewlett-Packard, założono tam w 1937 roku. Silna zależność od kształtujących się przez bardzo dlugi okres instytucji spolecznych (.zależnośc od szlaku") może mieć rzeczywiscie miejsce w wielu przypadkach. Na przyklad, w Polsce granice zaborów często do tej pory są granicami regionów o różnym poziomie aktywności gospodarczej. Z drugiej strony przykład Doliny Krzemowej lub, jeszeze bardziej, szybkiej modernizacji w Hiszpanii w latach 70. świadczy o tym, że niekorzystne obyczaje i instytucje odziedziczone z przeszlości nie stanowią jakiegoś faturn. W sprzyjających okolicznościach mogą one ulec radykalnej zmianie.

35 Ibidern, 5. 269. 
nych korzyści" 36 . Po pierwsze, wynika to stąd, że sieci zwiększają koszty zachowań niekooperacyjnych. Putnam powoluje się w tym miejscu na teorię gier, pisząc, że sieci obywatelskiego zaangażowania zwiększają powtarzalność i powiązanie gier, co ułatwia kooperację. Po drugie, „sprzyjają one powstawaniu mocnych form wzajemności" 37 . I wreszcie, ułatwiają przeplyw informacji o osobach bẹdących w takiej sieci. Putnam w swoich analizach koncentruje się na sieciach, których spoiwem jest działalność społeczna, kulturalna i polityczna, ale dużo miejsca poświęca równieź przedstawieniu sieci rotacyjnych kredytów.

Poziome sieci przyczyniają się do sprawniejszego funkcjonowania systemu politycznego. Mogą one też wpływać na rozwój gospodarki (zazwyczaj pośrednio, ale czasami, jak w przypadku sieci rotacyjnych kredytów - bezpośrednio). Pionowe, takie, jak silne na Południu Włoch Kościół i mafia, dają odwrotny skutek. Putnam, chyba nie bez złośliwej satysfakcji, której powody nie są znane, stwierdza: „Dobry rząd jest we Włoszech produktem ubocznym amatorskich zespołów muzycznych i klubów piłkarskich, a nie modlitwy"38

Istnieją dwie podstawowe przyczyny, dla których pionowe sieci nie przyczyniają się do wzrostu zaufania i współpracy. Po pierwsze, ,jest mniej prawdopodobne, aby sankcje, które zabezpieczają normy wzajemności przed oportunizmem, zostały nałożone 'na tych co na górze' i mniej jest prawdopodobne, że jeśli zostaną nałożone to bẹdą zaakceptowane", oraz, po drugie, "pionowy przepływ informacji jest często mniej godny zaufania niż przepływ poziomy, po części dlatego, że osoby podległe wykorzystują informację jako zabezpieczenia przed wyzyskiem"39.

Według autora Demokracji w działaniu im dłuższe są tradycje aktywności obywatelskiej i samoorganizowania się dla osiągania socjalnych, kulturalnych, a nawet sportowych celów, tym lepiej. Wtedy też stowarzyszenia będą mocniejsze, wzrastać będzie ilość zaufania, i rozwijać się demokracja i gospodarka. Nietrudno było zauważyć i nie umknęlo to uwadze samego Putnama, że twierdzenia o wielkich korzyściach wynikających z działania silnych stowarzyszeń są sprzeczne z teorią Mancura Olsona ${ }^{40}$. Według Olsona duźa ilość małych, silnych grup interesu prowadzi do obniżenia efektywności gospodarki, gdyż wpływają one na tworzenie korzystnego dla nich i niekorzystnego dla całej gospodarki prawa (np. powodują wzrost protekcjonizmu i wzrost redystrybucji PKB przez rząd). Stwierdza on, że „organizacje specjalnych interesów i zmowy zmniejszają efektywność gospodarki i zagregowany dochód w społeczeństwach, w których działają i sprawiają, że również życie polityczne jest bardziej spolaryzowane” oraz że „narastanie redystrybucyjnych koalicji powo-

36 Ibidem, 5. 269.

37 Ibidem, s. 270.

38 Ibidem, s. 274. Kilka zdań weześniej, na stronie 273, stwierdza on, że sprzynajmniej we Wloszech najbardziej żarliwie praktykujący katolicy charakteryzują się najmniej obywatelską orientacją".

39 Ibidem, S. 271 .

40 Zob. M. Olson. The Rise and Decline of Nations, Yale University Press, New Haven, 1982. 
duje wzrost złożoności regulacji, zwiẹkszenie roli rządu (...) i zmienia kierunek ewolt:cji społecznej". Kilka zdań wcześniej formuluje również nastẹpujący wniosek: „Koalicje redystrybucyjne zmniejszają moźliwości spoleczeństwa do przyswajania nowych technologii oraz do realokacji zasobów w odpowiedzi na zmianę warunków gospodarowania i w konsekwencji zmniejszają stopę wzrostu gospodarczego"41. Podczas gdy zdaniem Putnama stabilność państwa moźe przyczynić się do jego rozkwitu, to w opinii Olsona jest na odwrót. Obaj zgadzają się, że stabilność wplywa na wzrost ilości dobrowolnych stowarzyszeń i organizacji. Zdaniem pierwszego, powoduje to zwiększenie zaufania w społeczeństwie, natomiast drugi z autorów uważa, że rezultatem będzie większa ilość zmów, skomplikowanie prawodawstwa i „instytucjonalna skleroza”.

Putnam nie zgadzał się z tezami Olsona, gdyż uwaźał, że zgromadzone przez niego i jego zespół dane empiryczne dotyczące rozwoju regionalnego Włoch od $1970 \mathrm{r}$, potwierdzają twierdzenia o dobroczynnym wpływie tworzenia się stowarzyszeń oraz organizacji i zarazem „akumulacji” kapitału społecznego.

\section{Dwa typy kapitału społecznego - interpretacja wyników badań przeprowadzonych przez Avnera Greifa}

W ostatnich latach, już po opublikowaniu ksiąźki Putnama, największy wplyw na myślenie o sposobach współpracy i ich wpływie na funkcjonowanie gospodarki i społeczeństwa mialy artykuły Avnera Greifa, a w szczególności opublikowany w 1994 r. w Joumal of Political Economy. Nie pojawia się w nim pojęcie kapitału społecznego, nie jest też cytowany ani Putnam, ani Coleman, tym niemniej wpisuje się on dokładnie w debatę o tym jakiego rodzaju powiązania między ludźmi mogą tworzyć kapitał społeczny i obecnie jest on jednym z najczęściej cytowanych artykułów w tejże debacie.

Artykul Greifa, podobnie jak prace Colemana, też należy do nurtu prac, w których narzędzia ekonomii służą do opisu zjawisk wcześniej bẹdących poza dziedziną analiz ekonomicznych. Tymi narzędziami są tu modele płacy motywującej, które z formalnego punktu widzenia przynależą do teorii gier. W szczególności różne formy organizacji społeczeństwa są tu interpretowane jako samowymuszające się stany równowagi. Moźliwe jest modelowanie różnych form organizacji, gdyż gry przedstawione przez Griefa charakteryzują się wielością stanów równowagi.

Celem Greifa jest wyjaśnienie różnic instytucji handlu, a nawet więcej, bo głównych wyznaczników organizacji spoleczeństwa w świecie islamskim w jedenastym wieku i Genui w dwunastym wieku. Twierdzi on, że ich przyczyną były wierzenia (przekonania) kulturowe (ang. cultural beliefs). Należy zaznaczyć, że bierze on pod uwagę nie ich wszelkie rodzaje, ale tylko ich specyficzny podzbiór, który nazywa racjonalnymi wierzeniami kulturowymi. Używając języka ekonomii są one właściwie wspólnymi oczekiwaniami mającymi za przed-

41 Ibidem, s, 74 
miot działania innych w różnych okolicznościach. Zbiór możliwych wierzeń kulturowych ogranicza się do tych, które są samowymuszające. Dzieje się tak dlatego, ponieważ Greif przyjmuje, że wierzenia kulturowe są identyczne i powszechnie znane. Wierzenia kulturowe mogą być więc formalnie przedstawione jako odwzorowanie kombinacji strategii równowagi w zbiór rozkładów prawdopodobieństwa.

W odróżnieniu od strategii, które są częścią opisu „rozgrywanej” w rzeczywistości gry i które są niezaleźne od tego, co ludzie myślą o grze, wierzenia kulturowe są charakterystyką postaw ludzi wobec gry. Ukształtowały siẹ one w odniesieniu do konkretnej gry i wpływają zarazem na decyzje w kolejnych rozgrywkach. Inaczej mówiąc przeszłe wierzenia kulturowe wplywają na koordynacje oczekiwań i wpływają na to, które stany równowagi stają się punktami skupienia uwagi. W ten sposób oddziałują one na selekcję stanów równowagi i w rezultacie na to, jakie instytucje są ustanawiane przez społeczeństwo ${ }^{42}$.

Kupcy Maghrebu byli rządzącą się własnymi prawami (kalifat przyznał im prawo samorządu), przede wszystkim spolecznością żydowską, działająca w świecie muzułmańskim. Zdaniem Greifa cechowała ich kolektywistyczna kultura, co było związane z kolektywizmem ówczesnego islamu i z równieź kolektywistycznymi wartościami samej kultury żydowskiej (co np. wyrażało siẹ w haśle: „Cały Izrael jest odpowiedzialny za każdego członka społeczności”). Kupcy Genui byli pod wpływem indywidualistycznego chrześcijaństwa (w opini Greifa „w centrum swej teologii chrześcijaństwo w owym czasie umieszczało raczej jednostkẹ niż jej grupẹ społeczną") ${ }^{43}$. Obie grupy zajmowały się handlem na dużych przestrzeniach, na skalę międzynarodową, ale sposób organizacji handlu był całkiem inny i zdaniem Greifa.wynikało to właśnie z przekonań kulturowych.

Prowadzac interesy w daleko oddalonych od siebie miejscach kupcy obu społeczności rzadko mogli to czynić osobiście - byłaby to bardzo nieefektywna forma handlu - musieli więc korzystać z usług pełnomocników (agentôw). W przypadku kupców Maghrebu pełnomocnikami mogli się stać tylko czlonkowie tej samej społeczności o sprawdzonej reputacji. Wymóg ten nie obowiązywał w Genui. Kupcy Maghrebu, aby być pewnym czy zawierają umowę z osobą uczciwą, musieli inwestować w zbieranie informacji. Istniał także obowiązek dzielenia się informacją oraz obowiązek karania nieuczciwych pełnomocników. Kara polegała na odmowie zawierania transakcji i wykluczeniu ze społeczności. Można więc mówić o kolektywnym mechanizmie wymuszania dotrzymywania umów.

Greif przedstawia szczególowo logikę działania instytucji opierając się, jak to już było wspomniane, na modelu zaczerpniętym z teorii gier. Przykładowo konsekwencją optymalizacji w modelu jest wniosek, że w przypadku przeka-

42 A. Greif, Cultural beliefs and the organization of society: a historical and theoretical reflection on collectivist and individualist societies," Journal of Political Economy", 1994, t. 102, nr 5. s. 915.

43 Ibidem, s. 923. 
zania pełnomocnictwa kupcowi Maghrebu placa mogłaby być niższa, gdyż jej rola jako bodźca do zachowania uczciwøści nie byla tak waźna, jak w przypadku organizacji handlu przez Genueńczyków. Zasadniczym bodźcem do dotrzymania kontraktu przez kupca Maghrebu była obawa, że w razie złamania kontraktu jego oczekiwane przyszłe dochody jako mocodawcy stawały siẹ bliskie zeru.

Jak to było już wzmiankowane, kupcy Maghrebu przekazywali pełnomocnictwa tylko w ramach własnej społeczności. Nie byly one przekazywane nawet innym społecznościom żydowskim, np. żydom włoskim. Według jednego ze źródeł do badań nad handlem Maghrebu, na 97 pelnomocników tylko dwóch było muzułmanami. Kontrakty miały przy tym zazwyczaj nieformalny charakter. Kolejną cechą tej organizacji handlu było to, że każdy kupiec mógł zarazem pełnić rolę pelnomocnika - nie było podziału ról. Nawet najbiedniejszy kupiec mógł być mocodawcą dla bardzo bogatego kupca. Istniały dwie podstawowe formy współpracy: spółka i tzw, formalna przyjaźń. W przypadku spółki zyski byly dzielone proporcjonalnie do wnoszonego kapitału i pracy. „Formalna przyjaźń” polegała natomiast na tym, że dwaj kupcy działający w różnych miejscach oferowali sobie wzajemne usługi przedstawicielstwa bez płacenia za nie. Struktura tej społeczności była więc bezklasowa i pozioma (horyzontalna). Z drugiej, struktura dystrybucji dochodów była prawdopodobnie bardzo stabilna - szybkie powiększanie bogactwa (pionowa mobilność) raczej nie występowało.

Zajmująca się handlem społeczność Genui funkcjonowała na odmiennych zasadach. Przekazywanie informacji nieformalnymi kanałami było tam rzadkie. Uważano nawet, że interesy należy prowadzić przy zachowaniu daleko idącej dyskrecji. Nie wystẹpowało ograniczenie w rekrutowaniu pełnomocników. Mogly nimi być osoby nie będące obywatelami Genui, co bardzo ułatwiało handel z innymi krajami. Z drugiej strony, rzadkie było występowanie kupców posiadających kapitał w roli pełnomocników. Można rzec, że istniał podział klasowy. Związane to bylo też z tym, że zbyt wysokie byłoby wynagrodzenie kupca posiadającego kapitał za wypełnienie zadań pełnomocnika. Zdolne jednostki specjalizujące się w pełnomocnictwie mogly jednak szybko wzbogacić cię i zmienić swój status społeczny. Tak więc w Genui występowała dość duża mobilność społeczna. Z czasem było nawet wiẹcej kupców wywodzących się z niższych klas niż ze szlachty.

Coraz większego znaczenia zaczęły też nabierać formalne instytucje wymuszające stosowanie się do umów lub wymuszające innego rodzaju reguły użyteczne w handlu. Dla przykładu Genua wprowadzała embargo na handel z krajami, w których władza zawłaszczała dobra należące do kupców z tego miasta. Kupiec nie przestrzegający embarga mógł być przykładnie ukarany. Inne określone prawem innowacje to umowy dotyczace frachtu, handel udziatami oraz przedsiębiorstwo rodzinne (w spoleczności kupców Maghrebu nie wykształciło się przedsiębiorstwo rodzinne). 
Greif sugeruje, że logika obu systemów organizacji handlu ma znamiona uniwersalnej, gdyż kraje rozwijające się mają ją podobną do tej, która tu została opisana jako kolektywistyczna, a kraje bogate cechuje kultura i organizacja indywidualistyczna. Według niego w krajach bogatych kooperacja występuje w poprzek przynależności grupowych - nie jest ona ograniczona do wyodrębnionych grup etnicznych, religijnych lub rodzinnych.

Greif podaje również bardzo intrygujący fakt dotyczący utrzymywania się „racjonalnych wierzeń kulturowych”. Okazuje się, że mogą one być trwałe jeśli istnieje odpowiadająca im struktura organizacyjna. Żydowscy kupcy Maghrebu zniknęli jako osobna grupa - wtopili się w inne społeczności żydowskie - w krótkim czasie po tym, gdy zakazano im handlu. Nie naleźy jednak nie doceniać znaczenia kultury, bo może ona zdaniem Greifa, w decydujący sposób wpływać na funkcjonowanie gospodarki i społeczeństwa. Środowisko, w którym żyli kupcy Maghrebu i Genui pod wieloma względami było podobne, w szczególności nie występowały znaczne różnice w technologii ${ }^{44}$. O różnych ścieżkach rozwoju zadecydowały właśnie wierzenia kulturowe. Jak podkreśla Greif mogą przez bardzo długi okres czasu wyznaczać stan równowagi, który nie jest stanem optymalnym.

Użyty przez Greifa model wydaje się dobrze opisywać mechanizmy lączące kulturę i funkcjonowanie gospodarki. Ponadto rzeczywiście sprawia wrażenie, że opisuje on powszechne zaleźności. Przyczyną tego może być właśnie zastosowanie teorii gier, która nie zawiera żadnego założenia, które świadczyłoby o historycznej czy geograficznych ograniczeniach aplikacji. Z drugiej strony, wybrany model jest dość szczególnym modelem, zawierającym stosunkowo mocne załoźenia (np. o wiedzy wspólnej) i jest wielce prawdopodobne, że inne modele też będą całkiem dobrze pasować do zebranych faktów. Jest to tym bardziej możliwe, gdyż weryfikacja modelu nie ma charakteru ilościowego, ale polega na porównaniu logiki modelu ze stylizowanymi faktami. Ostatnie zarzuty można jednak odeprzeć twierdząc, po pierwsze, że w historycznych porównaniach społeczeństw nie zawsze można dokonywać dokładnych weryfikacji liczbowych. Po drugie, być może dany model będzie zastąpiony przez lepsze, co jest naturalnym procesem w nauce, ale jego zastosowanie i tak stanowi postęp w porównaniu z wcześniejszymi nie dość precyzyjnymi analizami historycznym i socjologicznymi.

Dzię̧ki pracy Greifa może w szczególności nastąpić postęp w dyskusjach dotyczących kapitału społecznego. Okazuje się bowiem, że występujące pomiędzy kupcami Genui powiązania miały charakter raczej bezosobowy, formalny, pionowy i niezależny od żadnej grupy odniesienia ${ }^{45}$. Tak więc kapitał społeczny Genui, która bez wątpienia osiągnęła wielki sukces polityczny i gospodarczy, wydaje się być inny od tego, który był opisywany przez Putnama. Bẹdąc

44 Używając jẹzyka odległego od jẹzyka glównego nurtu ekonomii można by rzec, że w tym wypadku siły wytwórcze nie determinowały stosunków wymiany.

45 Por. E.F. McClennen, Social capital and econonic growth, 1998. Maszynopis nie publikowany: 
Świadomym pojawiających się tu uproszczeń, pierwszy typ kapitału można nazwać indywidualistycznym, a drugi - kolektywistycznym. Podobne spojrzenie na sposoby współpracy można wyczytać z rezultatów badań nad rolą zaufania w Stanach Zjednoczonych i w Japonii przeprowadzonych przez Yamagishi.

\section{Dwa typy kapitału społecznego - interpretacja wyników badań przeprowadzonych przez Toshio Yamagishi}

Chociaż Toshio Yamagishi publikuje w czasopismach socjologicznych i psychologicznych, to jego teoria jest nawet bliższa neoklasycznej ekonomii niż poglądy Greifa. Podczas gdy w koncepcji Greifa pojawienie się danych wierzeń kulturowych ma charakter egzogeniczny, to według Yamagishi oczekiwania w stosunku do innych osób są pochodną kalkulacji wynikających z życia w okreŚlonym otoczeniu instytucjonalnym. Oczekiwania te mogą się przekształcić w stosunkowo trwałe predyspozycje, ale ich źródło tkwi właśnie w kalkulacjach jednostek. W każdym społeczeństwie jednostki ważą potencjalne korzyści oraz straty wynikające z działań przy danych ograniczeniach instytucjonalnych.

Yamagishi powołuje się na nową ekonomię instytucjonalną i na prace Olivera Williamsona, twierdząc, że generalnie cechuje go takie samo podejście do badania instytucji, gdyż w swoich analizach rówrież wychodzi od twierdzenia, że konkretne rozwiązania instytucjonalne wybierane są przez lüdzi na podstawie kalkulacji kosztów transakcji i kosztów utraconych możliwości (tak więc i w tym przypadku mamy do czynienia z "imperializmem ekonomii”).

Podstawową kategorią w teorii Yamagishi jest „niepewność społeczna”. Podmiot stoi w obliczu społecznej niepewności, gdy:

(1) osoba, z którą ma współdziałać może mieć powody do działania w taki sposób, że poniesie on jakieś koszty (lub, że wyrządzona mu będzie krzywda);

(2) nie ma on wystarczającej informacji, aby przewidzieć czy ta osoba rzeczywiście będzie działać w taki sposób ${ }^{46}$.

Yamagishi twierdzi, że „niepewność społeczna jest powszechna w ludzkiej społeczności. Angażujemy się w relacje z innymi, aby zwiększyć nasz, materialny lub psychologiczny, dobrobyt. Wchodząc w relacje odsłaniamy zarazem swe słabe miejsca. Dążymy do zwiększenia naszego dobrobytu podejmując jednocześnie ryzyko poniesienia kosztów. Poslugujemy się terminem 'niepewność społeczna' w odniesieniu do ryzyka bycia wykorzystanym w społecznych interakcjach" 47 .

46 T. Yamagishi, K.S. Cook i M. Watabe, Uncertainty, trust, and commitment formation in the United States and Japan, „American Journal of Sociology", 1998, t. 104, nr 1, s. 165-194, W innej pracy Toshio Yamagishi i Midori Yamagishi (T. Yamagishi i M. Yamagishi, Trust and commitment in the United States and Japan, „Motivation and Emotion”, 1994, t. 18, nr 2, s. 133) spoleczna niepewnosć opisana jest trochẹ innymi stowami: jest to „struktura o mieszanych bodźcach, w której podmiot nie ma moźliwości prawidłowego wykrycia intencji partnera".

47 T. Yamagishi, K. Cook i M. Watabe, op. cit., s. 170. 
Istnieją dwa sposoby rozwiązywania problemu niepewności społecznej. Są nimi: zaufanie i zabezpieczenie się (ang. assurance). Zaufanie opiera się na wnioskach dotyczących cech charakteru i intencji osoby, z którą mamy wspóldziałać. Zaufanie może przybierać dwojaką postać. Po pierwsze, możemy wy. różnić zaufanie oparte na wiedzy i dotyczące poszczególnych bytów (osób lub organizacji). Po drugié, możemy wyróźnić ogólne zaufanie, które jest przekonaniem o życzliwości jako składowej natury ludzkiej ${ }^{48}$. Zabezpieczenie się polega z kolei na rozpoznaniu, na posiadaniu wiedzy o strukturze bodźców, która związana jest z daną relacją z drugą osobą. Taką relację Yamagishi nazywa relacją zobowiązania się lub zaangażowania się (ang. commited relation). Zaufanie jest charakterystyczne dla indywidualistycznego społeczeństwa, a zabezpieczanie się - dla kolektywistycznego.

Oba rozwiązania mają swoje wady i zalety - nie istnieje ponadczasowa wyźszość, któregoś z nich. To otoczenie i właściwości ich samych decydują, które jest lepsze. Jak to będzie dokładniej przedstawione w następnym rozdziale, jeśli wzrasta niepewność społeczna to wzrasta zapotrzebowanie na zabezpieczanie się przed jej skutkami. Gdy natomiast otoczenie oferuje coraz więcej atrakcyjnych możliwości, to zabezpieczanie odbywa się coraz większym kosztem. Relacje, które są generowane przez poszczególne rozwiązania można nazwać kapitałem społecznym ${ }^{49}$. Co za tym idzie, można sformułować tezę, że istnieją dwa podstawowe typy kapitału społecznego, które występuja w różnych społeczeństwach. Na szybki rozwój Japonii wpłynął inny typ kapitału społecznego niż na rozwój Stanów Zjednoczonych. Należy jednak podkreślić, że nieuprawnione są tu twierdzenia o jakimś determinizmie dziejowym narodów, gdyż kapitał społeczny może ulec zmianie. Jest wielce prawdopodobne, że Japonia znowu zacznie się rozwijać, gdy relacje zostaną oparte przede wszystkim na zaufaniu, a nie zabezpieczaniu się̧50.

Przejście od jednego do drugiego sytemu organizacji społeczèństwa nie następuje jednak natychmiast. W szczególności trudne jest zerwanie relacji zobowiązania się. Yamagishi podaje cztery powody tych trudności. Po pierwsze, jeśli ludzie są juź w jakiejś relacji zobowiązania się, to z samej definicji tej relacji wynika to, że nie reagują na każde zewnętrzne zmiany. Tak więc koszty alternatywne muszą być stosunkowo duże i muszą występować przez dluższy czas, aby doszło do zerwania. Po drugie, często pomiędzy osobami bẹdącymi w takich relacjach rozwijają się silne związki emocjonalne. Może siẹ też tak

48 Zob. T. Yamagishi i M. Yamagishi, op. cit., s. 139.

49 Jak to już było wcześniej zaznaczone, sam Yamagishi nie posługuje się pojęciem „kapitalu spolecznego". Włączenie tego pojẹcia do jego teorii wydaje się być jednak bardzo naturalne. Ponadto dzięki temu latwiej można się przekonać, że istnieje wiele rodzajów kapitału spolecznego. I znôw, jak w przypadku koncepcji Greifa, można by mówić o dwóch głównych ty. pach kapitalu spolecznego: kolektywistycznym i indywidualistycznym. Typ kapitału nie bytby tu, jak to było u Greifa, uzależniony od wierzeń kulturowych, ale od zestawu instytucji (i bodźców), które oddziałują na jednostkę.

50 Takie przypuszczenie wyrazil Toshio Yamagishi w 1996 r. podczas rozmowy z autorem niniejszego artykulu. 
zdarzyć, że relacja z daną osobą staje się bardzo cenna właśnie ze względu na nią, a nie ze względu na korzyści jakie daje dana relacja. Po trzecie, wzajemne zobowiązania ośmielają do inwestowania w specyficzne aktywa, na przykład do inwestowania w urządzenia, które przydatne są dla tej konkretnej relacji ${ }^{51}$. Po czwarte, zaangażowanie się w relacje zobowiązania (np. członkostwo w bardzo zwartej grupie) może wpłynąć na percepcję ryzyka związanego z zerwaniem związków. „Percepcja ryzyka lub subiektywna niepewność społeczna może być wyższa wśród tych, którzy zwykle mają do czynienia z członkami grupy (ang. insiders) związanymi relacją zobowiązania niż u tych, którzy regularnie kontaktują się z osobami nie będącymi członkami grupy (ang. outsiders). W takim razie, zobowiązanie się może w rzeczywistości zmniejszyć poziom zaufania do nie należących do danej grupy, i w rezultacie, ci, którzy głównie pozostają w zapewniających bezpieczeństwo relacjach zobowiązania, odczuwają wyższą subiektywną niepewność. Innymi słowy, relacja zobowiązania się może wytworzyć błędne koło nieufności w stosunku do obcych: ci, którzy nie ufają obcym pozostają w relacjach zobowiązania i ponieważ unikają obcych, to stają się jeszcze bardziej nieufni w stosunku do nich"52.

Opisane wcześniej mechanizmy powodujące inercję kolektywizmu można zaobserwować w Japonii. Ich konsekwencją jest to, że „Japończycy są tak przyzwyczajeni do Środowiska, w którym kolektywne systemy wzajemnego karania gwarantują współdziałanie w grupie, że czuliby się niepewnie w środowisku społecznym bez takiego systemu wzajemnego monitorowania i komunikowania"53. Obserwacje te wydają się być bardzo wiarygodne, gdyź Yamagishi wraz ze współpracownikami przeprowadził rozległe badania porównawcze w Japonii i Stanach Zjednoczonych. Były to zarówno badania ankietowe, jak też i teoriogrowe eksperymenty z dostarczaniem dóbr publicznych (inaczej mówiąc były to eksperymenty z dylematem więźnia). Uzyskane wyniki, między innymi, podważyly dwa szeroko rozpowszechnione mity o Japończykach, którym uległ również Fukuyama. Stwierdza on między innymi, że „Stany Zjednoczone, podobnie jak Japonia i Niemcy, wykazują na przestrzeni historii trwałą tendencję do tworzenie społeczeństwa o wysokim poziomie zaufania, zorientowanego na dobro grupy, mimo iż Amerykanie uznają się za naród zdecydowanie indywidualistyczny" 54 .

Jeśli uznać badania przeprowadzone przez Yamagishi za rozstrzygające, to powyższa opinia nie jest prawdziwa. Po pierwsze, wbrew poglądom wielu autorów, w tym Fukuyamy, na podstawie badań ankietowych doszedł on do

51 W tym kontekście aktywami moźe być nie tylko kapitał rzeczowy - termin ten może być tu interpretowany bardzo szeroko. T. Yamagishi i M. Yamagishi, op. cit., s. 137, zauważają, że „takie spoleczne i psychologiczne aktywa, jak serdeczne wspomnienia dobrej przeszlości i wzajemnego zrozumienia, mogạ być równieź uznane za aktywa specyficznie związane z daną relacją".

52 T. Yamagishi i M. Yamagishi, op. cit., s. 137.

53 T. Yamagishi, K. Cook i M. Watabe, op. cit., s. 169.

54 F. Fukuyama, op. cit., S. 20. 
wniosku, że Japończycy charakteryzują się niższym poziomem zaufania niż Amerykanie. Po drugie, podważył też tezę o kolektywistycznym nastawieniu (rozumianym jako bezwarunkowa identyfikacja z kolektywem) Japończyków. W badaniach eksperymentalnych, w których identyfikacja z grupą mogłaby mieć wpływ na poziom kooperacji, okazywało się, że Amerykanie czẹściej współpracują niż Japończycy. Dopiero wprowadzenie systemu wzajemnych kar spowodowało znaczny wzrost kooperacji. „Tak więc pokazane zostało, że 'kolektywistyczne' zachowanie - kooperacja w celu zwiększenia dobrobytu grupy jako całości - wśród Japończyków utrzymywało się przede wszystkim dzięki systemowi wzajemnego monitorowania i karania, a nie dzięki jakiemuś przypuszczalnemu 'systemowi wartości', zgodnie z którym jednostki wyżej cenią dobrobyt grupy niż własny interes" 55 .

\section{Zakończenie}

Wprowadzenie do nauk społecznych pojęcia kapitału społecznego okazało się być bardzo owocne zarówno dla dyskusji teoretycznych, jak też dla badań empirycznych. Zarazem okazało się, czego początkowo nie dostrzegano, że konieczne jest wyróżnienie różnych rodzajów kapitału społecznego. Wstępne wyniki badań, w szczególności prowadzonych przez Greifa i Yamagishi, pokazują także, że kapitał społeczny może być tworzony i może przyczyniać się do rozwoju gospodarczego także w liberalnych, otwartych i indywidualistycznych społeczeństwach. Co więcej takie spoleczeństwa mogą lepiej prosperować od wielu innych spoleczeństw opartych na silnych związkach wspólnotowych. Precyzyjne stwierdzenie jakie relacje wspólnotowe niszczą kapitał społeczny, jakie mogą przyczyniać się do jego tworzenia, a jakie mają charakter neutralny, wymaga jednak dalszych żmudnych badań.

55 Ibidem, S. 169. 